Peer-reviewed scientific periodical, focusing on legal and economic issues of antitrust and regulation.

\title{
The Interaction of Public and Private Enforcement of Competition Law Before and After the EU Directive - a Hungarian Perspective
}

\author{
by
}

\section{Tihamér Tóth*}

\section{CONTENTS}

I. Introduction

II. Public and private enforcement of competition rules

III. Private enforcement of competition law in Hungary

IV. Liability for damages under EU law

1. EU case law

2. The Directive

3. Hungarian law and jurisprudence

V. Regulating the interaction of public and private enforcement

1. EU law

2. The Directive

3. Hungarian law and practice

3.1. The friendly interaction: Amicus Curiae

3.2. The hierarchical interaction: the binding effect of competition authority's decisions

3.3. Discovery and leniency

VI. Beyond the Directive: the case for class actions

1. EU law and the Recommendation

2. Hungarian law and practice

VII. Conclusion

* Assistant professor, Pázmány Péter Catholic University, Budapest, Hungary; of counsel at Réczicza Dentons Europe LLP; toth.tihamer@jak.ppke.hu. Article received: 25 May 2016; accepted: 17 November 2016.

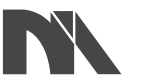
at the promotion of education. 


\section{Abstract}

The paper explores the changes the EU Directive on harmonizing certain rules governing actions for damages under national law for infringements of the competition law provisions will bring about in Hungary, with a special focus placed on damages liability rules, the interaction of public and private enforcement of these rules, and the importance of class actions. Amendments of the Competition Act introduced in 2005 and 2009 had created new rules to promote the idea of private enforcement even before the Directive was adopted. Some of these rules remain unique even now, notably the legal presumption of a $10 \%$ price increase for cartel cases. However, subsequent cases decided by Hungarian courts did not reflect the sophistication of existing substantive and procedural rules. There has only ever been one judgment awarding damages, while most stand-alone cases involved minor competition law issues relating to contractual disputes. The paper looks at the most important substantial rules of tort law (damage, causality, joint and several liability), the co-operation of competition authorities and civil courts, as well as at (the lack of) class action procedures from the perspective of the interaction of public and private enforcement of competition law.

\section{Résumé}

Le document analyse les changements apportés par la directive européenne relative aux certaines règles régissant les actions en dommages et intérêts en droit national pour les infractions aux dispositions du droit de la concurrence en Hongrie, en particulier concernant les règles sur la responsabilité civile en matière de dommages, l'interaction de l'application publique et privée du droit de la concurrence et l'importance des recours collectifs. Les modifications à loi de la concurrence introduites en 2005 et 2009 ont créé de nouvelles règles pour promouvoir l'idée d'une application privée du droit de la concurrence même avant que la directive a été adoptée. Certaines de ces dispositions sont toujours uniques, notamment la présomption légale d'une augmentation de prix de $10 \%$ par les ententes. Néanmoins, les jugements ultérieurs rendus par les tribunaux ne reflétaient pas les règles de fond et de procédures sophistiquées. Il n'y avait juste le jugement qui a accordé des dommages et intérêts, alors que la plupart des actions autonomes ( «stand-alone actions ») portaient sur des problèmes secondaires du droit de la concurrence liés aux conflits contractuels. Larticle examine des règles les plus importantes du droit de la responsabilité civile (le dommage, la causalité, la responsabilité solidaire), la coopération entre les autorités de la concurrence et les tribunaux civils, ainsi que l'absence de mécanisme de recours collectifs et de la perspective de l'application publique et privée du droit de la concurrence.

Key words: private enforcement of competition law; public enforcement; discovery; leniency; damages; joint and several liability; amicus curiae; class action; representative action.

JEL: K13; K15; K21; K41 


\section{Introduction}

This paper explores the changes the EU Directive on certain rules governing actions for damages under national law for infringements of the competition law provisions ${ }^{1}$ (hereinafter, the Directive) will bring about in Hungary, with a special focus placed on damages liability rules, the interaction of public and private enforcement of these rules, and the importance of class actions.

The decentralisation of competition law enforcement through Regulation No. $1 / 2003^{2}$ coincided with the enlargement of the European Communities. Abolishing the Commission's monopoly on exempting competition restricting agreements made it more likely that national judges would apply EU competition rules. The Hungarian legislator followed suit and so the exemption procedure was also phased out under national competition law in 2005. Soon after the new implementing regulation entered into force, the Commission issued a Green Paper on damages actions for breaches of the EC antitrust rules in $2005^{3}$. Its goal was to understand why there have been so few litigations before national courts and to propose appropriate legal and policy measures. Since then, Commission press releases heralding each new cartel decision have ended with a short paragraph drawing the attention of injured parties to their rights under EU law to start follow-on damages actions ${ }^{4}$.

The Commission submitted its White Paper on damages actions for breach of the EC antitrust rules in April 20085. This act suggested the need for a reform

1 Directive 2014/104/EU of the European Parliament and of the Council of 26 November 2014 on certain rules governing actions for damages under national law for infringements of the competition law provisions of the Member States and of the European Union, OJ L 349, 05.12.2014, p. 1.

2 Council Regulation (EC) No. 1/2003 of 16 December 2002 on the implementation of the rules on competition laid down in Articles 81 and 82 of the Treaty (hereinafter, Regulation 1/2003), OJ L 1, 04.01.2003, p. 1.

3 Commission Green Paper of 19 December 2005 - Damages actions for beach of the EC antitrust rules, COM(2005) 672, with an annexed Commission Staff Working Paper SEC 2005/1732 (hereinafter, Green Paper).

4 See, for example the press release in the industrial bags cartel case issued in November 2005: "Any person or firm affected by anti-competitive behaviour as described in this case may bring the matter before the courts of the Member States and seek damages, submitting elements of the published decision as evidence that the behaviour took place and was illegal. Even though the Commission has fined the companies concerned, damages may be awarded without being reduced on account of the Commission fine". Available at http://europa.eu/rapid/ press-release_IP-05-1508_en.htm?locale=hu (17.11.2016).

5 Commission White Paper on Damages actions for breach of the EC antitrust rules, COM(2008)165 final, accompanied by a Commission Staff Working Paper SEC(2008)404 (hereinafter, White Paper). 
of national procedural rules, like the standing of indirect consumers, collective redress, access to evidence, the binding nature of decisions of national competition authorities (hereinafter, NCAs), and the estimation of harm. The White Paper started a discussion spanning many years, which finally led the Commission to submit a proposal for a Directive in June 20136. In April 2014, the Parliament approved the Directive and, after its linguistic corrections, the Council formally adopted the Directive in November 2014. The Commission proposal excluded binding rules on collective redress in order to secure its easy approval by the Council and in the Parliament. This sensitive, but crucial topic was addressed in a non-binding recommendation adopted on the same day as a Proposal on competition law damages actions ${ }^{7}$. The third element of the legislative package consisted of soft law rules designed to aid judges to assess the quantity of damages caused by anti-competitive actions ${ }^{8}$.

Hungary did not wait for the outcome of the lengthy European law-making process. As early as 2005, and in line with the proposals of the Hungarian Competition Authority (hereinafter, $\mathrm{GVH}$ ), an amendment of the national competition law regime was prepared, intended to introduce new rules to promote the idea of private enforcement. The next wave of strengthening private enforcement occurred in 2009. Some of these national rules are now also reinforced by the EU Directive, some of them will retain their national origins, like the presumption of a $10 \%$ price increase created by cartels.

EU Member States have to implement the directive harmonizing national civil procedure rules and substantive rules as regards damages until December 2016. The Hungarian government submitted its proposal to the Parliament in October 2016. The new set of rules will cover not only EU but also national competition law related claims. This makes sense, since the vast majority of the few competition law based litigations so far have involved the application of Hungarian competition rules only. Interestingly, the implementation

6 Proposal of 11 June 2013 for a Directive of the European Parliament and of the Council on certain rules governing actions for damages under national law for infringements of the competition law provisions of the Member States and the European Union, COM(2013) 404 final. Available at: http://ec.europa.eu/competition/antitrust/actionsdamages/directive_en.html (17.11.2016).

7 Commission Recommendation 2013/396/EU of 11 June 2013 on common principles for injunctive and compensatory collective redress mechanisms in the Member States concerning violations of rights granted under Union law, OJ L 201, 26.07.2013, p. 60 (hereinafter, the Recommendation on collective redress).

8 See the Commission Staff Working Document of 11 June 2013 - Practical guide Quantifying harm in actions for damages based on breaches of Article 101 or 102 of the Treaty on the Functioning of the European Union, accompanying the Communication from the Commission on quantifying harm in actions for damages based on breaches of Article 101 or 102 of the Treaty on the Functioning of the European Union (OJ C 167, 13.06.2013, p. 19). See at http://ec.europa. eu/competition/antitrust/actionsdamages/quantification_guide_en.pdf (17.11.2016). 
process coincides with the adoption of a new civil procedural code. Yet the new, competition law related civil procedure and substantive rules will form a special chapter of the Competition $\mathrm{Act}^{9}$, rather than being incorporated into the code on civil procedure. There are two good reasons for this: first, the Competition Act hosted similar provisions in the past and second, the timing of the adoption of the code on civil procedure is uncertain.

It is within this broader context that this paper aims to explore how Hungary strived to establish a civil litigation friendly legal framework before and after the Directive. After outlining the rules introduced in 2005 and 2009, the next part of the paper is devoted to summarizing the practice of national civil law courts applying competition law. After recalling those main points of the Directive which deal with the interaction of public and private enforcement of competition rules, it will be concluded that new procedural rules, however important they seem to be, do not immediately result in more complaints being filed before courts. Soft factors such as competition law knowledge of parties, judges, local business culture and the overall civil procedural regime, including the availability of class actions, are even more important.

\section{Public and private enforcement of competition rules}

The main competition rules of the EU addressed to undertakings are set out in Articles 101 and 102 of the Treaty on the Functioning of the European Union (hereinafter, TFEU). Article 101(1) prohibits anti-competitive agreements, concerted practices and decisions by associations of undertakings; Article 102 outlaws abuses of a dominant position enjoyed in a significant part of the single market. Sections 11 and 21-22 of the Hungarian Competition Act incorporate similarly worded prohibitions. Under EU law, directly effective provisions which are sufficiently clear, unconditional and do not require the adoption of implementing measures can form the legal basis of a complaint before courts of Member States. Since the adoption of the new implementing Regulation 1/2013, the whole body of Articles 101 and 102 TFEU can be litigated before courts ${ }^{10}$. In Hungary, where the competition authority

9 Act No. LVII of 1996 on the prohibition of unfair and restrictive market practices (hereinafter, the Competition Act).

10 Cases where the Court acknowledged the direct effect of these provisions are, for example, Case 127/73 BRT v SABAM ECLI:EU:C:1974:6, para. 16; Case C-282/95 Guérin automobiles $v$ Commission ECLI:EU:C:1997:159, para. 39. Regulation 1/2003 abolished the EU Commission's exemption monopoly under paragraph (3) of what is now called Article 101 TFEU, allowing judges and national competition authorities to apply the whole article themselves. 
has always played the dominant role in enforcing competition rules, the Competition Act has long since made it clear that the procedure of the GVH cannot be an obstacle for civil law litigations initiates by private parties.

Competition rules can be enforced by public institutions with the aim of furthering public policy aims, or by individuals protecting their own interests before courts (Komninos, 2008, p. 11-12, noting that the question of the relationship between public and private enforcement must be seen in the context of the more substantive question of the goals of competition law norms). Public enforcement involves the enforcement of competition rules through criminal and administrative rules by a competition authority, whereas courts apply their own rules of civil procedure. The final decision or judgment in a public enforcement regime may impose sanctions on undertakings or on individuals, involving imprisonment in criminal law cases and heavy fines in administrative procedures. Plaintiffs can seek compensation for damages (where punishment does not play a role) or may challenge the legality of an anti-competitive agreement. In reality, private actions follow public procedures more often than not (follow-on actions), but can also be brought independently (standalone actions) where plaintiffs face a higher hurdle to prove their case.

In Europe, compliance with competition rules is mainly ensured through administrative procedures. Anti-competitive conduct is investigated and prohibited by competition authorities, including the European Commission. Private enforcement was never meant to substitute public enforcement, unlike in the U.S. where private litigations have always been seen as a way to further public interests in fields like environmental and consumer protection, misleading advertising, labour law, and antitrust ("social control model" vs. the more European model of "conflict resolution") (Shapiro, 1981, p. 24). Civil litigation was regarded by the Commission as a useful supplementary procedure that, if working well in practice, could even help achieve its public policy aims of deterring anti-competitive actions (Wils, 2016, p. 14).

The problem is that in many Member States, Hungary among them, not even this supplementing follow-on function of private enforcement seems to work. Alexander Italianer, former director general for competition, had to acknowledge in 2013 that only $25 \%$ of the antitrust infringements found by the Commission have been followed by civil claims over the eight preceding years. Moreover, most of these claims were brought in the UK, Germany and the Netherlands, where procedures are perceived to be more favourable ${ }^{11}$ (see also: Van Nuffel, 2016, p. 256, suggesting that Member States that so far attracted more damages actions may wish to implement the Directive in a way that preserves their attractiveness).

11 See: http://ec.europa.eu/competition/speeches/text/sp2013_06_en.pdf (17.11.2016). 


\section{Private enforcement of competition law in Hungary}

Litigating competition law issues before a civil court had been an option under Hungarian law even before Hungary's accession to the then existing European Communities. However, in those rare cases where competition law related pleas were raised before a civil court, judges suspended court procedures to await a decision of the $\mathrm{GVH}^{12}$. The positive side of such cautious judicial attitude, which is still well and alive today, was that the danger of inconsistent decisions has never been a serious issue in Hungary. Judges tend to respect the activity of the competition authority, and thanks to its unique decision-making process, they may even consider the Competition Council as a sort of specialized tribunal ${ }^{13}$.

Accession to the European Communities did not increase the number of competition law related private litigations. Pál Szilágyi summarized the practice of Hungarian courts in two papers published in 2013 and 2014 (Szilágyi, 2013, p. 136; Szilágyi, 2014, p. 168) by concluding that private competition law enforcement is still underdeveloped in Hungary. After studying 16 cases from between 2007 and 2012, Szilágyi noted that there was not a single private action which had stood the chance of succeeding (Szilágyi, 2013, p. 141).

With this background, it was with the enthusiasm of an explorer that the first Hungarian judgment awarding damages for a competition law infringement could be presented during the research project conducted for the Fide Congress in 2016 in the capacity as a national rapporteur (Tóth, 2016, p. 549).

Now, due to the focus of this paper which centres on the interaction of private and public enforcement, focusing on follow-on cases of the past years, it can be concluded that they related to public procurement cartel cases decided by the GVH between 2004 and 2008. Interestingly, none of the cases on anti-competitive agreements referred to the application of EU law. Publicly

12 See, for example, the judgment of the second instance court of Szeged in 2004, Szegedi Ítélőtábla: Gf.I.30.351/2003.* sz. (BH 2004. 151.). The Hungarian Ashurst report criticized the practice of the courts because procedural rules did not, in fact, restrain courts assessing an infringement of competition rules as one of the elements of liability for damages, but only reserved the competence of the competition authority procedure (and not of the civil procedure) for the Competition Office. See Éless and Németh, p. 2. In 2005, a new Article 88/A was introduced into the Hungarian Competition Act which provided that "the power of the Hungarian Competition Authority to proceed (...) and used to safeguard (...) the public interest, shall not prevent civil law claims, arising out of the infringement of the provisions (...) [on unfair manipulation of business decisions, cartels and abuse of dominant position], from being enforced directly in court".

13 The GVH is an independent authority. Within the GVH, infringement decisions are adopted by the Competition Council, which is a separate body within the authority, with its members enjoying judge-like independence. 
owned companies responsible for the organization of road construction tenders sued several corporations fined by the competition authority. They did not prevail though, mainly for procedural reasons. The courts argued that the plaintiffs lacked legal standing - instead of the public company organizing the construction tenders, the State itself could have suffered damages ${ }^{14}$. Privately initiated lawsuits were thus not able to fulfil their mission of supplementing an earlier public enforcement measure.

For example, the Metropolitan Court of Appeal agreed with the first instance court which had refused to award damages despite a GVH decision proving a public procurement cartel ${ }^{15}$. The courts rightly observed in these cases that the Civil Code's rules on non-contractual liability should be applied, even if a contract existed between the parties. The court held, however, that no damage was proven, neither by the plaintiff, nor by the court appointed expert. The judicial expert estimated the "but for price" of the roads to be constructed and concluded that it is for the judge to decide whether the HUF 75 million (EUR 243,000) difference amounts to damage or not. The expert pointed out that the actual cartel-related price only involved a modest $0,9 \%$ profit rate, compared to the industry average of 5.2\%. The courts agreed that the lack of extra-profit suggested that no damage was caused to the plaintiff (or the State). There was also a lack of causality: the Metropolitan Court of Appeal explained that the GVH established a market allocation cartel, which does not prove that prices were driven up by the undertakings (it was not a price cartel) ${ }^{16}$. Judicial reasonings like these prove that there is still need for improving the competition law and economics awareness of judges.

There were also unique follow-on litigations based on commitments decisions adopted by the $\mathrm{GVH}^{17}$. For example, the judgment delivered by the Regional Court of Appeal of Győr on 3 July 2014 approved the ruling of a first instance court that had established the infringement of Hungarian antitrust rules and awarded damages ${ }^{18}$. The GVH started its investigation

14 Judgment of the Curia of 29.01.2013 in Gfv.30284, appeal against the judgment of the Metropolitan Court of Appeal No. 14.Gf.40.088/2012/11. The Metropolitan Court noted that even if the plaintiff suffered some damage, it was ultimately passed on to the State.

15 14.Gf.40.600/2012/6. This case also shows how lengthy follow-on litigation can be. The public procurement tenders related to road constructions were conducted in 2002. The GVH imposed the fines in 2005, after which it took almost two years for the plaintiffs to start the litigation - the final judgment was handed down in 2012.

16 This lack of microeconomic knowledge may suggest that judges might benefit from some more training.

17 These are not typical follow-on actions since the competition authority does not establish the existence of an anti-competitive conduct, but rather terminates the investigation in light of the commitments offered by the undertakings.

18 Pf.V.20047/2014/5. 
against a decision of the Trade Board of Győr, defining it as an association of undertakings despite its public law origins. The procedure involved only Hungarian competition law concerning both anti-competitive agreements and the abuse of a dominant position. In its preliminary position ${ }^{19}$, the $\mathrm{GVH}$ argued that some of the rules relating to the use of assigned parking places used exclusively by taxis may be abusive. However, after the Trade Board promised to change its rules, the GVH terminated the procedure making the commitments binding in September 2007.

In a follow-on litigation, the plaintiff was awarded damages already in the first round of the litigation in 2008. However, the first instance judgment was annulled by the regional court of appeal in 2011 due to procedural flaws. The second round of the judicial procedure brought the same positive result for the plaintiff. This time the court of appeal agreed with the first instance court's decision of December 2013 and the plaintiff taxi company was awarded HUF 3 million (EUR 9,700) in damages.

The nature of commitments is that they do not establish the existence of an infringement or the lack thereof. As a result, the order of the GVH cannot have any binding effect on judges. Yet, as this case shows, the very existence of a previous competition law procedure and the reasoning of the order may help plaintiffs prove their case.

To sum up, the role of private enforcement has been quite unnoticeable on the development of competition law in Hungary. Neither have there been judgments in cases of significant economic or business importance, nor were there ever sizeable damages awarded in follow-on litigations. Most issues decided by civil law judges related to minor contractual disputes where competition law played a minor role only. In many of the few stand-alone private litigation cases available in the public register of the Hungarian courts $^{20}$, competition law issues had no merit. The low number of follow-on cases could be the result of non-transparent, out of court settlements. Alternatively, it may also be due to the GVH's strong focus on cases involving "by object" restrictions, where there is no need to prove actual harm. This may make public investigation less complex, but it is certainly bad news for plaintiffs.

The next part of the paper will present the most important provisions of the Directive relating to substantive civil law issues. It will be followed by a discussion of the rules on the interaction of public and private enforcement.

19 Equivalent to the statement of objection (SO) issued by the EU Commission.

${ }^{20}$ See http://birosag.hu/ugyfelkapcsolati-portal/anonim-hatarozatok-tara (17.11.2016). 


\section{Liability for damages under EU law}

\section{EU case law}

Both EU and Hungarian laws acknowledge the right of injured parties to bring an action for damages against companies that infringed EU or domestic competition rules. The EU Court's Courage judgment of 2001 confirmed that the right to claim damages also exists under EU law, contributing to the effective enforcement of EU competition rules ${ }^{21}$. The Court of Justice further clarified the conditions for exercising the right to claim damages in the Manfredi case ${ }^{22}$.

The jurisprudence of the Court helps identify those persons who can come forward with an EU law based damage action. The ECJ made it clear in Courage $v$ Crehan that even a party that signed the anti-competitive contract enjoys that right ${ }^{23}$.

Unlike in the U.S., the Court has not limited the right to sue for damages to direct purchasers ${ }^{24}$. General principles of civil law countries in Europe allow each and every person that suffered damages to have access to courts.

Another building block of EU substantive civil law is that according to Manfredi, individuals can claim compensation for the harm suffered if there is a causal relationship between that harm and an agreement or practice prohibited under Article 101 TFEU $^{25}$.

21 Case C-453/99 Courage and Crehan ECLI:EU:C:2001:465, paragraph 26: “...the full effectiveness of Article 85 of the Treaty [subsequently Article 81 EC and then Article 101 TFEU] and, in particular, the practical effect of the prohibition laid down in Article 85(1) would be put at risk if it were not open to any individual to claim damages for loss caused to him by a contract or by conduct liable to restrict or distort competition".

22 Joined Cases C-295/04 to C-298/04 Manfredi and Others ECLI:EU:C:2006:461 (clarifying the rights of indirect purchasers downstream in the supply chain and the fact that there was no need to prove fault in order to establish a claim).

23 Case C-453/99 Courage and Crehan ECLI:EU:C:2001:465, paras 24 and 31-34. Crehan was a pub tenant seeking damages against its beer supplier, Courage. The Court found that the beer supply agreement could be considered as an anti-competitive agreement under Article 101(1). In order to reconcile the reasoning with general principles of law, the Court emphasised that this challenge is available against an undertaking that bears significant responsibility for the distortion of competition.

24 The Supreme Court, mainly for practical reasons to avoid multiple damage payments, denied indirect purchasers standing under federal antitrust law. See the ruling in Illinois Brick Co. v. Illinois 431 U.S. 720 (1977). However, most States recognize standing of indirect purchasers. See, for example: Antitrust Modernization Commission - Report and Recommendations 265-283 (2007).

25 Joined Cases C-295/04 to C-298/04 Manfredi and Others ECLI:EU:C:2006:461, paras 60-61; Case C-199/11 Otis and Others ECLI:EU:C:2012:684, para. 65. 
Relying upon the principles of effectiveness and the right of individuals to seek full compensation for loss caused by an anti-competitive conduct, the injured persons must be able to seek compensation not only for actual loss (damnum emergens) but also for loss of profit (lucrum cessans) plus interest ${ }^{26}$. It is not entirely clear to what an extent does the loss of profit cover the "loss of a chance", which has been referred to in a few cases on EU non-contractual liability ${ }^{27}$ and is considered harm to be compensated under the tort laws of England and France.

In Otis, a case related to the Commission's lift cartel decision, the Court applied the notion of "direct causal link" as a requirement for compensation of damages caused by an infringement of EU competition law ${ }^{28}$. This suggests that the causal link should not be broken by an independent decision taken by the seller that is a "non-cartel member".

The Austrian Kone case ${ }^{29}$ raised another interesting liability issue: can a person be awarded compensation who did not have a contractual link with the cartelists but purchased the product at a higher price from a supplier that did not participate in the cartel? The plaintiff's argument would be that the cartel had an overall upward effect on prices, with innocent competitors following the price movements, so buyers of competing non-cartel members also suffered harm ("umbrella pricing"). The Court ruled that these persons should not be excluded from obtaining compensation for the loss caused by the cartel, even without having contractual links with the cartel members ${ }^{30}$.

For those aspects of tort liability where the Court did not intend to develop EU law relying on general legal principles (that is, the causal link, limitation periods, the use of punitive damages), it referred to domestic legal system of each Member State to "prescribe the detailed rules governing the exercise of that right ... provided that the principles of equivalence and effectiveness are observed" 31 .

${ }^{26}$ Manfredi, para. 100.

27 See, for example, Case T-13/92 Moat $v$ Commission ECLI:EU:T:1993:22, para. 48, and Case T-47/93 C v Commission ECLI:EU:T:1994:262, para. 54.

28 Case C-199/11 Otis and Others ECLI:EU:C:2012:684, para. 65.

29 Case C-557/12 Kone and Others ECLI:EU:C:2014:1317, para. 29-34.

30 The Court explained in Kone that "the victim of umbrella pricing may obtain compensation for the loss caused by the members of a cartel, even if it did not have contractual links with them, where it is established that the cartel at issue was, in the circumstances of the case and, in particular, the specific aspects of the relevant market, liable to have the effect of umbrella pricing being applied by third parties acting independently and that those circumstances and specific aspect could not be ignored by the members of the cartel", supra note 29, para. 34 .

31 Manfredi, para. 72. 


\section{The Directive}

Establishing non-contractual (tort) liability involves complex issues, most of which are not clarified under EU law. According to the Green Paper, Member States take diverse approaches as regards the level of culpability required $^{32}$. The White Paper envisaged a rule that any infringer undertaking would be liable for damages, unless it shows that it could not reasonably have been aware that its conduct had restricted competition. However, after the public consultation, the Commission omitted this rule from its proposal. The final text of the Directive mentions culpability as one of the conditions for compensation that Member States may maintain under national law, as long as this does not run counter to the principles of effectiveness and equivalence ${ }^{33}$. The Commission did not propose to fully harmonize national rules on harm and the causal link, except for the availability of the passing-on defence, the presumption of passing-on of overcharges to indirect purchasers, and the presumption that cartel infringements cause harm.

Cartels necessarily involve a joint infringement of competition rules. As a result, there should be joint and several liability for the harm caused. Each cartelist is bound to compensate for the harm in full. This principle, common to most EU Member States, has now been codified in Article 11(1) of the Directive. There are two categories of infringers for whom the harsh consequences of joint and several liability were tempered. One of these relates to the specific focus of this paper - the interaction of public and private enforcement. Leniency applicants, companies that actively supported the investigation of the competition authority are exempt [from joint and several liability], just like small or medium-sized enterprises. The Directive also laid down rules on the internal relationship between cartelists by requiring Member States to ensure that a cartel member may recover a contribution from any co-infringer, the amount of which is to be determined in the light of their relative responsibility for the harm caused by the infringement.

The Directive also introduced new EU-wide rules allowing national courts to estimate the amount of the damage. At the time of the adoption of its Proposal, the Commission issued a Communication on quantifying harm in damages actions based on competition law infringements, accompanied by a detailed Practical Guide to assist national courts. Plaintiffs are encouraged by the presumption of harm in Article 17(2). However, this presumption applies only to cartels ${ }^{34}$,

32 Green Paper, paras. 101-103.

33 Directive, recital 11.

34 Article 2(14) of the Directive gives an "official" definition for a cartel stating: "cartel means an agreement or concerted practice between two or more competitors aimed at coordinating their competitive behaviour on the market or influencing the relevant parameters 
not to vertical distribution disputes or abuses committed by a dominant undertaking. The Directive requires Member States to allow national courts to estimate the amount of harm where it is practically impossible to quantify the damage precisely ${ }^{35}$. Another issue where the interaction of public and private enforcement can be observed is that judges should also be able to request assistance from competition authorities, including the EU Commission, with respect to the determination of the quantum of the damage ${ }^{36}$.

\section{Hungarian law and jurisprudence}

6:579. $\S$ of the Civil Code establishes the general rule of liability in damages caused outside contractual relations as follows: anyone causing damages to another person by infringement of law shall compensate them. He is exempted from liability if he proves that he behaved as it is generally expected in the given situation. Proving culpability is thus part of a successful damages action ${ }^{37}$. Both intent and negligence can be a basis for liability for damages and there is no difference in their legal consequences.

According to 6:522. $\S$ of the Civil Code, full compensation comprises: (a) the loss of value of the property, (b) loss of expected property gain, and (c) the costs related to eliminating the detriment of property. If the amount of the damage cannot be calculated precisely, judges can also estimate an amount to achieve the aim of full compensation ${ }^{38}$. Punitive damages cannot be imposed.

The Hungarian Competition Act includes bonus provisions for plaintiffs eager to seek compensation due to an infringement of competition law already in its present form. $88 / \mathrm{C}$. $\S$ of the law provides for special rules intended to make the plaintiff's life more comfortable. When proving the extent of the influence that a cartel exercised on prices, it shall be presumed, unless the opposite is proven, that the infringement increased the price to an extent of $10 \%$. This provision, introduced in 2009 , comes close to a damage presumption

of competition through practices such as, but not limited to, the fixing or coordination of purchase or selling prices or other trading conditions, including in relation to intellectual property rights, the allocation of production or sales quotas, the sharing of markets and customers, including bid-rigging, restrictions of imports or exports or anti-competitive actions against other competitors".

35 Directive, Article 17(1).

36 Directive, Article 17(3). It is unlikely that the GVH could be of much help to Hungarian judges, since it usually does not make efforts to quantify the harm caused by a cartel.

37 However, the burden of proof is not on the plaintiff but rather on the party having caused the damage.

38 6:531. $\S$ of the Civil Code. 
as foreseen in the Directive. The defendants should prove that the price increase did not occur, that it was smaller [than 10\%], or that regardless of the price increase, the damage suffered by the plaintiff was not as high as the price rise itself, for example because the latter was passed on the vertical supply chain.

Despite this unique provision of Hungarian law, no judgment can be quoted where either the claim or the judgment relied on this rule ${ }^{39}$. It clearly did not lead to more private litigations. When it comes to quantifying the damage of an unlawful action, experts, especially court appointed "official" experts, tend to play an important role. The expert can use whatever method he sees fit to [assess] the facts of the case. For example, in the one and only successful Hungarian damages action so far, a small taxi company operating in Győr collected a compensation of HUF 3 million (EUR 9,700), plus interests ${ }^{40}$. This was an exclusionary conduct case based on both the prohibition of anticompetitive agreements and the abuse of dominance ${ }^{41}$. When calculating the amount of the damage (in the form of forfeited profit), the judges relied on the calculations provided by the court appointed expert. The plaintiff was also awarded interests, calculated from the year 2006, based on the average base interest rate of the Hungarian Central Bank ${ }^{42}$.

The new provisions of the Competition Act both supplement and modify the existing general substantive rules on damages found in the Civil Code. The new act will not overwrite the existing $10 \%$ price increase presumption; it will co-exist with the new damage presumption introduced according to the Directive.

Causality is not defined by the Civil Code. 6:521. § provides that there is a lack of causality when the damage was not foreseeable. Thus, objective predictability of damages triggered by an infringement should be a relevant factor. The alleged lack of a causal link was decisive for the Metropolitan Court, sustained by the Curia, when refusing to award damages to plaintiffs even though the GVH had established an unlawful cartel ${ }^{43}$. The court set a fairly high standard demanding that the plaintiff ought to have relied on witnesses and documents to prove that the price set in the contract was higher due to the cartel activity. In another case of 2012, the Metropolitan Court

39 The $10 \%$ presumption is applicable in court proceedings started after 1.06 .2009 even if the unlawful action occurred before the entry into force of this provision.

40 Pf.V.20047/2014/5.

${ }^{41}$ However, EU law was not invoked by the parties, which is understandable, since the legal dispute related to the taxi market in one single town in Hungary.

42 According to calculations made for the purpose of this analysis, the interest roughly doubled the value of the original damages claim.

43 Judgment of the Curia of 18.09.2012 in Gfv.30202, appeal against the judgment of the Metropolitan Court of Appeal No. 14.Gf.40.521/2011/9. 
of Appeal sided with the first instance court in refusing to award damages despite an earlier GVH decision establishing a public procurement cartel ${ }^{44}$. The court ruled that causality was not proven, since the GVH established a market allocation cartel, the court ruled that this does not prove that prices were raised by the undertakings. This case shows that even a follow-on law suit can be difficult to win.

As regards the Kone case law, the new section 88/I. (3) of the Competition Act will indirectly acknowledge the possibility of umbrella pricing based litigation. It does so when it mentions, in relation to the special joint and several responsibility of the successful leniency applicant, that a competition law harm may be caused not only to direct and indirect customers of the cartelists but also to third parties.

Finally, if two or more persons jointly cause the damage, they are jointly and severally liable for the harm ${ }^{45}$. The Hungarian Competition Act already provides a solution to the problem that this strict liability standard should not discourage leniency applicants to come forward. Obviously, a leniency applicant would be an easy target for plaintiffs. According to $88 / \mathrm{D}$. $\S$ of the Competition Act, a leniency applicant who received full immunity may refuse to pay damages as long as the claim can be recovered from other cartel members. To put it differently, the first leniency applicant is, at the moment, not even facing the immediate threat of paying for damages sustained by its own customers ${ }^{46}$. This rule is without prejudice to the possibility of bringing a joint action against persons causing the harm. Lawsuits initiated to enforce claims against persons responsible for harm-causing behaviour, to which immunity from fine was granted, shall be stayed until the date when the judgment made in the administrative lawsuit initiated upon request for a review of the decision of the Hungarian Competition Authority establishing the infringement becomes legally binding.

The rules of the Directive are stricter, so changes have to be made to current Hungarian provisions. For example, after the completion of the implementation process the new 88/I. $\S$ of the Competition Act will provide that a successful immunity recipient shall pay for the damages caused to its own customers, but it shall be liable to other injured parties only where full compensation cannot be obtained from other undertakings involved in the same infringement.

44 14.Gf.40.600/2012/6.

45 6:524. § (1) of the Civil Code.

46 Despite this rule, it cannot be said that many undertakings were applying for leniency. 


\section{Regulating the interaction of public and private enforcement}

\section{EU law}

The Court clarified in Zwartveld, based upon the general principle of sincere co-operation as envisaged by the loyalty clause of Article 5 EEC, that every Community institution, including the Commission, shall give active assistance to a national court hearing proceedings on the infringement of Community rules ${ }^{47}$. That may involve producing documents and authorizing its officials to give evidence in national proceedings. Although this case did not involve the application of competition rules, the co-operation obligation did extend to this legal field. Some years later, Article 15(1) of Regulation 1/2003 codified this obligation providing that national courts may pose questions to the Commission on both facts and its opinion on a case.

Article 15(3) of Regulation 1/2003 went a step further when it allowed both NCAs and the Commission to submit their views to national courts on their own initiative. This amicus curiae institution can also help achieve consistent law enforcement in Europe. Furthermore, Article 15(2) of the implementing regulation obliged national courts to send copies of judgments applying Articles 101 and 102 TFEU to the Commission. The Commission will thus be in the position to decide whether it intends to submit its observations at least during the appeal process.

One obvious problem with the co-existence of public and private enforcement is that the same anti-competitive conduct can be subject to two or even more parallel procedures. In order to avoid conflicting decisions, the EU Court clarified the relationship between the EU Commission and national courts in Masterfoods ${ }^{48}$. National courts cannot adopt judgments running counter to a Commission decision dealing with same case. If a national court and the Commission are conducting their proceedings in parallel, the national judiciary shall avoid taking a decision contrary to the Commission's anticipated decision. As a result, the national court should consider suspending its procedure and await the outcome of the Commission's case. On the other hand, the Commission cannot be bound by a previous judgment of a national court, even if it applies EU competition rules. The revised implementing Regulation 1/2003 codified the Masterfoods case law mentioned above in its Article 16(1).

47 Zwartveld, order of the Court in C-2/88, EU:C:1990:315.

48 Case C-344/98 Masterfoods and HB ECLI:EU:C:2000:689, paras 48-52. 


\section{The Directive}

Recital 6 of the Directive recalls that it is essential to ensure the interaction of private and public enforcement in order to ensure the maximum effectiveness of competition rules. It is necessary to regulate the coordination of those two forms of enforcement in a coherent manner so as to avoid divergence in applicable rules, jeopardizing the proper functioning of the internal market.

The Directive sets out the following rules coordinating the enforcement of competition rules by competition authorities, and the enforcement of the same rules in damages actions by national judges:

- disclosure of evidence included in the file of a competition authority (Article 6), and limits on the use of evidence obtained solely through access to the file of a competition authority (Article 7),

- the effect of decisions issued by NCAs on judges (Article 9 (1) and (2)),

- the limitation period is suspended or interrupted, if a competition authority takes action (Article 10(4)),

- a NCA may assist its judiciary with respect to the determination of the quantum of damages (Article 17(3))

\section{Hungarian law and practice}

Hungary introduced specific rules following the model of Regulation 1/2003 in 2005. The new rules implementing the Directive will not bring about major changes.

\subsection{The friendly interaction: Amicus Curiae}

In order to help the court interpret competition law norms, the GVH may act as amicus curiae, just like the European Commission ${ }^{49}$. The GVH's annual report $^{50}$ presented to the Parliament about its activities in 2013 mentioned nine amicus curiae interventions, compared to six such cases in the previous year ${ }^{51}$, most of which involved questions of abuse of dominance and unfair

49 According to 88/B. $§(1)$ of the Competition Act, private lawsuits involving anticompetitive agreements or abuse of a dominant position, the provisions shall be notified to the GVH. The competition authority may decide to act as amicus curiae according to paragraphs (3)-(5) or "take over" the case to conduct its own competition supervision procedure according to paragraph (6).

50 Available at: http://www.gvh.hu//data/cms1029344/gvh_ogy_pb_2013.pdf (17.11.2016).

51 Of these cases, four related to abuse of dominance, one concerned anti-competitive agreements and one the deception of consumers. 
commercial practices. For example, in a case relating to the exclusion of a retailer from the distribution network of branded watches, the GVH argued for the lack of a dominant position, but advised that an unlawful resale price maintenance issue can be involved. Interestingly, each of these amicus curiae cases involved the interpretation of domestic competition rules. This can be seen as a sign of the general reluctance of Hungarian judges to apply nonHungarian law.

The old-new chapter of the Competition Act will allow for amicus curiae interventions as regards the facts of the case, its legal evaluation, plus, and this will be new, the damage caused by the infringement. Amicus curiae observations, unlike a decision, are not binding. The novelty brought about by the implementation of the Directive lies in the possibility of a damage related intervention. The GVH may help courts by giving its opinion about the existence of damage, its size, and the existence of causality. Such intervention will remain optional for the GVH - the authority will be able to refuse to assist the court, even without giving reasons for its reluctance to give aid. It has to be argued here however that whenever a judge presents a genuine cartel case to the $\mathrm{GVH}$, the authority will not be able to allow itself not to help the judge. This new provision may even push the GVH to specifically investigate the damage related facts of the case in the course of its own procedure, putting more details into the reasoning of its decisions, thereby making the amicus curiae procedure redundant.

\subsection{The hierarchical interaction: the binding effect of competition authority's decisions}

The vast majority of damages actions in Europe, unlike in the U.S., follow public enforcement actions by the EU Commission or by the NCAs. This makes the question of the effect of these administrative decisions crucial. According to Article 9(1) of the Directive, a competition law infringement should be "deemed to be irrefutably established for the purposes of an action for damages brought before their national courts". Although the term "binding effect" is carefully avoided, the provision does not allow civil law courts to indirectly challenge the findings of a given Member State's competition authority. Recital 34 of the Directive emphasizes that re-litigating competition law cases before civil courts would reduce legal certainty, and lead to inconsistency in the application of Articles 101 and 102 TFEU.

Traditionally, Hungarian judges are neither accustomed to being bound by decisions of an administrative body, nor by a judgment of an administrative review court. The special and central role played by the Commission in enforcing EU law and the EU Court's subsequent review process may make 
the Masterfoods approach reasonable. To extend the same principle to decisions by the NCAs demands a different explanation emphasizing the special knowledge of these institutions and their decision-making process integrated into the European Competition Network. Notably, the EU Commission can and does make its position known to the NCAs, so a judge can presume that the decision is in line, or at least not against the position of the EU Commission, whose decision would be binding on them. This policy choice also reflects that public enforcement stands higher in the hierarchy than private enforcement.

Hungary had already regulated the evidentiary effect of infringement decisions well before the Directive was adopted. These rules cover not only Articles 101 and 102 TFEU, but also their national equivalents. A separate chapter of the Hungarian Competition Act is dedicated to provisions to sustain a consistent application of the law. Section $88 / \mathrm{B}(6)$ provides that when the $\mathrm{GVH}$ notifies the court hearing a case relating to competition rules that it has decided to start its own investigation, the court shall stay its proceeding. Furthermore, national courts are bound by the final GVH decision irrespective of whether it establishes the existence or the lack of an infringement ${ }^{52}$.

However, this rule was interpreted narrowly by the Curia, the supreme court in Hungary, in one case ${ }^{53}$. This made the legislator amend the provision making it clear that the binding effect cannot be limited to those cases where the judge had asked the GVH for its opinion on a given case. Now the Directive also strengthens this broader view on the binding nature of a NCA decision.

The new 88/R. § (1) repeats the existing provisions. The novelty lies in the fact that it also deals with the effects of decisions adopted by NCA of other Member States. The Directive acknowledged only their prima facie evidentiary value. The Hungarian version will imply that those parts of these decisions which explain the infringement shall be adopted as facts.

\subsection{Discovery and leniency}

In the seminal Pfleiderer judgment the Court stressed the need for balancing, on the one hand, the interest of victims of a competition law infringement to have access to crucial evidence and, on the other hand, the interest of maintaining the effectiveness of public enforcement of competition rules,

52 Orders from the GVH terminating the procedure due to lack of sufficient evidence, or approving commitments offered by an undertaking, have no binding effects on courts.

53 Gfv.IX.30.152/2011/10, published as EBH 2012.G.1. The same approach was followed in case Gfv.IX.30.202/2012/9. Admittedly, this binding effect of a GVH decision is a unique phenomenon in the domestic legal system. As a rule, a court is never bound by the decision of an administrative authority (4. § of the Act on Civil Procedures). 
including the leniency program ${ }^{54}$. The Directive includes detailed rules regulating the relations between leniency and damages actions. Specifically, the Directive and its Hungarian implementing measures allow a limited access only to leniency related documents, which is also extended to settlement statements and witness statements in the course of a criminal procedure (88/N.§ (1)). Also, as described above, the burden of joint and several liability is eased for the immunity recipients.

\section{Beyond the Directive: the case for class actions}

\section{EU law and the Recommendation}

Competition law infringements tend to cause harm to more than one undertaking or consumer. As a rule, several buyers may suffer an individual harm each of which is not that serious to make bringing legal proceedings a risk for a cartel member. Whenever a jurisdiction believes that wrongdoers should not retain their illicit profits, special procedural rules are adopted to combine small individual claims into one large lawsuit. The legislator may authorize consumer protection associations $\mathrm{s}^{55}$ or public bodies to sue on behalf of the public (representative actions). Another way to merge individual claims is to provide for class actions, where named plaintiffs would sue for damages suffered by a group of consumers. An 'opt out' class action is a favoured procedural tool in the U.S., whereas European jurisdictions seem to prefer the more conservative and less efficient 'opt in' version. The difference between these small words 'in' and 'out' is significant. If a jurisdiction chooses to go with the 'opt out' class action, the mega-suit would involve all unnamed individuals who purchased a product within a defined time period from the infringers. If a customer prefers to bring its own case, he or she can do that by expressly notifying the court at an early stage of the proceedings. Failing to do so will result in a judgment, or more often a settlement, binding that consumer even if he or she never ever entered the courtroom. An 'opt in' system means that a person will be bound by the judgment only if he or she expressly notifies the court initially about his or her intention to join the lawsuit as a party.

54 C-360/09 Pfeiderer AG v. Bundeskartellamt, judgment of the Court (Grand Chamber) of 14.06.2011; (2011) ECR I-05161.

55 Note worty, well established consumer protection associations include Which? in the UK and Verbraucherzentrale Bundesverband in Germany. 
Neither the Commission nor its co-legislators were enthusiastic about going with the U.S. type of class action, emphasizing its principal incompatibility with traditional European legal tradition as well as its potential for abuses ${ }^{56}$. In the end, the Directive did not include rules on collective redress so that other rules of the new regime would not be delayed. Instead, the Commission adopted in June 2013 a Recommendation to provide for collective redress mechanisms. Along with the wishes of the EU Parliament, the recommendation applies not only to competition law infringements but also consumer and environment protection as well as financial services. This recommendation can be regarded as a soft form of harmonization. Concerning collective damages actions, the Commission recommends an 'opt in' system, unless another approach would be "duly justified by reasons of sound administration of justice" 57 . Furthermore, the recommendation seems to protect the interests of large companies by discouraging Member States from admitting contingency fees and punitive damages.

The recommendation also invites Member States to ensure that collective redress actions should only be started once the procedure of the competition authority has been concluded ${ }^{58}$. This delay will not lead to claims being time barred, since the Directive provides that limitation periods should be suspended or interrupted during the course of a public enforcement procedure ${ }^{59}$.

The inadequacy of opt-in class actions is proven not only by the U.S. experience (Waller, and Popal, 2016, p. 2.). Poland introduced a law on collective actions in 2009 based on an opt-in model. Since then, no successful competition law cases have been brought (Jurkowska-Gomułka, 2016, p. 10; Piszcz, 2016, p. 203). In the UK, before October 2015, collective proceedings were allowed only for follow-on cases on an opt-in basis. Furthermore, the law named one pre-authorized representative party to bring such cases - the consumer association Which?. The new Consumer Rights Act 2015 allows both opt-in or opt-out proceedings, not only in follow-on cases but also in standalone $\operatorname{cases}^{60}$. In the case of opt-out proceedings, class members domiciled in the UK are automatically included in the class, unless they opt-out. The Competition Appeal Tribunal (hereinafter, CAT) will play an important role

56 European Parliament resolution of 02.02.2012 on 'Towards a Coherent European Approach to Collective Redress' (2011/2089(INI), point 2: "Europe must refrain from introducing a US-style class action system or any system which does not respect European legal traditions".

57 Recommendation on collective redress, point 21.

58 Recommendation, point 33.

59 Article 10(4).

60 The previous system failed to produce cases. Only one collective action was brought by Which? on behalf of 130 consumers who had been overcharged by producers of replica football shirts. 
in authorizing these classes to avoid any abuse of the system ${ }^{61}$. The new rules follow the law of the U.S. by creating high standards for representatives of the class of plaintiffs. The CAT should consider various factors including whether the proposed representative would fairly and adequately act in the interests of the members, whether the proposed class representative has a material interest that may conflict with the interests of the class members. Also the proposed representative's financial resources will be of importance, including the ability to pay its own as well as the opposing side's legal costs.

It should be noted that British law does not follow the Commission Recommendation as far as the requirement is concerned that the representative entity should have a non-profit making character ${ }^{62}$. As a result, not only consumer bodies but also law firms and third party funders can bring class actions.

\section{Hungarian law and practice}

In Hungary, the institution of class actions is not present in the civil procedure system, and would be considered as alien by most academics. Instead, 92. $\S$ of the Competition Act provides for a representative action, also extending to damages claims, with some opt-out features that can be initiated exclusively by the GVH. Paragraph (1) authorizes the GVH to file an action to enforce civil law claims of consumers where unlawful practices, belonging to the competence of the authority, concern a large, definable group of consumers. According to paragraph (2), this is a unique "follow-on" kind of action: the GVH is empowered to file such action only where it has already commenced its own investigation.

The problem is that this instrument has not been tested in antitrust cases yet. This shows that public authorities are not interested in launching such burdensome litigations falling outside their traditional duties. The GVH has initiated one single representative action so far in a misleading advertising case, where the claim concerned the declaration of nullity only and did not involve the award of damages ${ }^{63}$.

The new Civil Procedure Code adopted in November 2016 will introduce some changes as regards collective actions. It will regulate representative actions more broadly. However, this will not be new for the competition law

61 Competition Appeal Tribunal's Rules 2015, especially Rules 75-97, available at: http:// www.legislation.gov.uk/uksi/2015/1648/made (17.11.2016).

62 Recommendation, 4(a).

63 The Municipal Court ruled in May 2012 that some provisions of the general terms of contracts drafted by Ingatlandepo, the operator of a real estate website, were null and void. 
field since the GVH is even now empowered to take such actions. The code also provides for a special class action procedure on an opt-in basis. This, however, will be limited to disputes involving labour law, environmental law issues and consumer products related claims. All in all, the legislator still believes that authorities are best placed to bring public interest law suits, no 'privatization' of these claims is seriously envisaged.

\section{Conclusion}

Hungary had already put in place procedural rules to encourage private enforcement of Hungarian and EU competition rules back in 2005 and later in 2009. As a result, the Directive will not bring about huge changes as regards the binding effect of final decisions issued by the GVH on civil courts ${ }^{64}$, the favoured position of leniency applicants in terms of joint and several liability ${ }^{65}$, or the assumption of damage caused by a cartel ${ }^{66}$. The implementation of the Directive will bring about changes with respect to various procedural questions such as discovery, handling of confidential information, and access to the GVH's file. Hungary, just like many other Member States, will introduce the new rules not only for cases involving the application of EU but also domestic competition rules. Furthermore, Hungary decided to extend the implementation of the rules not only to damages claims, but also to any other civil law related claim.

A sceptical attitude has to be expressed as to the extent to which this reform streamlining existing rules will lead to more private enforcement in Hungary. Special rules introduced in the past did not have the desired impact either (Müller-Graf, 2016, p. 178, noting that the overall picture is mixed: while domestic legal systems provide for sufficient remedies, these are used to varying extents with various chances of success in Member States). Part of this may be the result of weak procedural rules, most of which will now be amended as a consequence of the Directive.

${ }^{64}$ Although the Supreme Court has ruled recently that this should be interpreted narrowly to apply only in cases where the civil court suspended its procedure seeking an amicus curiae opinion from the authority, there are legislative works underway on an amendment and to make the language of the act clearer. See: Szilágyi, 2012.

65 Furthermore, Section 88/D. of the Competition Act provides that lawsuits filed to enforce claims against the leniency applicant shall be stayed until the date when the judgment made in the administrative lawsuit initiated upon a request for a review of the decision of the Hungarian Competition Authority establishing an infringement becomes legally binding.

66 Section 88/C. of the Competition Act does not directly refer to the size of the damage but refers only to a presumed 10 per cent increase in prices. 
However, it is likely that it will be hard for legislation to cure the main problems behind this passive attitude. Different tools and more time is needed if the aim is to counteract the unawareness of the combined application of competition rules and civil law by plaintiffs, or the reluctance of judges to apply a highly technical legal field such as competition law, especially when this would also involve the interpretation of "foreign" EU rules.

As far as consumer products are concerned, the lack of effective opt-out class actions will deter individual consumers from joining forces. Similar representative actions cannot fill the vacuum. The GVH has not used its existing toolkit over the past years to take a stance against enriched cartelists. Why should it do so in the future?

The lack of follow-on actions may exemplify a critique towards the enforcement record of the GVH: the competition authority might target perceived competition law infringements which did not really cause harm to anyone, at least not to an extent that would make them consider starting a litigation process lasting for years. From this point of view, the planned amendment of the Competition Act, expressly making the compensation of harm a factor that may reduce the fines imposed, could prove to be an extra motivating factor if not for litigation, than at least for settling the bills cartelist owe to their customers ${ }^{67}$.

\section{Literature}

Éless, T. and Németh, Á. (2004). Hungary. Retrieved from: http://ec.europa.eu/competition/ antitrust/actionsdamages/national_reports/hungary_en.pdf (17.11.2016).

Jurkowska-Gomułka, A. (2016). Nätional Report - Poland. In Gy. Bándi, P. Darák, P. Láncos, T. Tóth (eds), Private Enforcement and Collective Redress in European Competition Law, Congress Proceedings, Vol. 2. Budapest: Wolters Kluwer, 516-531. Komninos, A.P. (2008). EC Private Antitrust Enforcement - Decentralised Application of EC Competition Law by National Courts. Oxford: Hart Publishing.

Müller-Graf, P.Ch. (2016). General report. In Gy. Bándi, P. Darák, P. Láncos, T. Tóth (eds), Private Enforcement and Collective Redress in European Competition Law, Congress Proceedings, Vol. 2. Budapest: Wolters Kluwer, 66-132.

Piszcz, A. (2016). Practical Private Enforcement: Perspectives from Poland. In M. Bergström, M. Iacovides, M. Strand (eds), Harmonising EU Competition Litigation, The New Directive and Beyond. Oxford and Portland: Hart Publishing, 203-220.

Shapiro, M. (1981). Courts, A Comparative and Political Analysis. Chicago: University of Chicago Press.

67 New 78. § (1) of the Competition Act. It should be added that the wording of this rule could have been stronger, obliging the Competition Council to take the fact of a compensation payment into account. Taking damages payments into consideration is an option already now under the existing rules on the imposition of fines. 
Szilágyi, P. (2012). Hungarian Competition Law \& Policy: The Watermelon Omen. Retrieved from: https://www.competitionpolicyinternational.com/hungarian-competition-lawpolicy-the-watermelon-omen-3/ (17.11.2016).

Szilágyi, P. (2013). Private Enforcement of Competition Law and Stand-alone Actions in Hungary. Global Competition Litigation Review, 3, 136-142.

Szilágyi, P. (2014). The Hungarian Experience on Private Enforcement and Class Actions. Global Competition Litigation Review, 3, 168-172.

Tóth, T. (2016). National Report - Hungary. In Gy. Bándi, P. Darák, P. Láncos, T. Tóth (eds), Private Enforcement and Collective Redress in European Competition Law, Congress Proceedings, Vol. 2. Budapest: Wolters Kluwer, 399-420.

Van Nuffel, P. (2016). Institutional report. In Gy. Bándi, P. Darák, P. Láncos, T. Tóth (eds), Private Enforcement and Collective Redress in European Competition Law, Congress Proceedings, Vol. 2. Budapest: Wolters Kluwer, 134-176.

Waller, S.W. and Popal, O. (2016). The Fall and Rise of the Antitrust Class Action. World Competition: Law and Economics Review, 39(1), 29-55. Retrieved from: http://dx.doi. org/10.2139/ssrn.2641867.

Wils, W.P.J. (2016). Private enforcement of EU antitrust law and its relationship with public enforcement. Forthcoming in World Competition: Law and Economics Review, 40(1), 2017. Retrieved from: available at: https://papers.ssrn.com/sol3/papers.cfm?abstract $\mathrm{id}=2865728$ (7.11.2016). 